\title{
An approach for prioritisation of national interests of the EU Member States
}

\section{Maya Bozhilova ${ }^{a}$, Yantsislav Yanakiev ${ }^{a}$, Nikolai}

\section{Stoianov ${ }^{a}$, Dimitar Stoyanov ${ }^{a}$}

a Bulgarian Defence Institute "Prof. Tsvetan Lazarov"

2 Prof. Tsvetan Lazarov Blvd. 1592, Sofia, Bulgaria

https://www.di.mod.bg/

\section{A BSTRACT}

This article aims to propose a methodology for national interests' prioritisation. It starts with the study and definition of the key term - national interest. The focus of the definition is on the long-term and comparatively stable ends that the nations aim to achieve. Then, the paper presents an overview of the existing methods for national interests' evaluation. The main section of the article is focused on the proposed approach for prioritization of the national interests of the EU Member States, based on methods for expert evaluation, and more exactly, the evaluation is done applying Analytic Hierarchy Process. Finally, an illustrative example is described to verify and validate the proposed methodology.

The research was conducted during the work on the EU project PYTHIA [1]. 
ARTICLE INFO

RECEIVED: 01 Sep 2019

REVISED: 10 Nov 2019

ACCEPTED: 30 Dec 2019

ONLINE: 20 MAY 2020
KEYWORDS

National interests, National interests' prioritisation, AHP, Decision making, PYTHIA project

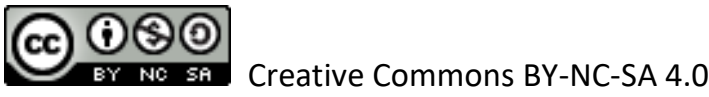

\section{INTRODUCTION}

This article presents the result from the research, performed under the PYTHIA (Predictive methodologY for TecHnology Intelligence Analysis) project. PYTHIA is a research project that has received funding from the European Union's Preparatory Action for Defence Research - PADR programme. The objective of the project is to develop an innovative methodology for performing strategic technology foresight in the defence domain [1].

Over the centuries the concept of national interest has been related to continuous conflicts and wars because of the pursuit by all nations of their national interest. There exists close interrelation between geopolitics and national interests. The concept of "national interest" is and will continue to be a basis of international relations and politics. Nowadays we are witnesses of broadening the meaning of the concept which in addition to the survival of the nations, includes also the wellbeing of the people, their, culture, social consensus, levels of economic prosperity, demographic situation, etc. The focus of the definitions is on the long-term and comparatively stable ends that the nations aim to achieve. The appropriate evaluation and prioritisation of the national interests is the starting point for the identification of security risks and defence policy formulation and implementation to allocate adequate resources and to take proper actions to achieve the desired ends.

The understanding the interrelationships between the process of evaluation of national interests and defence technology foresight is the basis for the future EU defence capabilities development. The idea is to make evident the logic of this process, which starts with the prioritization (evaluation) of the national interests, identification of risks and opportunities to those interests related to the technologies development, potential means to defend the national strategic goals, and concludes with the determination of critical defence capabilities to protect the interests of the member state and the EU as a whole.

The efforts of researchers in the military domain are focused on developing solutions, implementing new technology opportunities, to support capabilities developments to protect national defence interests. These new technology solutions include an application of information technology in collaborative environment [2], mobile ad hoc networks [3], cloud computing and data centres [4]. Therefore, for supporting strategic decision-making, the military analysts 
should have the means for prioritization of national interests and performing strategic technology foresight.

To achieve the relevant national interests' prioritization, the paper proposes an approach in form of a methodology for prioritization (evaluation) of the national interests of the EU member states based on methods of an expert's evaluation. The core of the methodology is the decision-making method - Analytic Hierarchy Process [5].

\section{The "NATIONAL INTERESTS" CONCEPT}

One of the most frequently cited political scientist Donald Neuchterlein [[6] argues that the term "national interest" has been used by political leaders and scholars since the founding the nation-states to describe the aspiration and goals of sovereign entities in the international area. In his later works, Neuchterlein further developed the use of the concept of "national interest" as a tool for both analysis and policy development. He defined the term "national interests" as "the perceived needs and desires of one sovereign state concerning the sovereign states comprising its external environment" [6], and differentiating it from the "public interest" which refers to dealing with the internal domestic environment. Besides, the author developed a template that offers definitions of four versions of national interest (Survival, Vital, Major, and Peripheral) based on their relative intensity [7].

The approach of Donald Neuchterlein applied to determine and classify national interests is presented in table 1.

Table 1: National Interests Matrix (Adaptation from Donald Neuchterlein, "National Interests and National Strategy," in Terry L. Heyns, ed., Understanding U.S. Strategy: A Reader, Washington, DC: National Defense University, 1983, p. 38.)

\begin{tabular}{lllll}
\hline List $\quad$ of National & \multicolumn{3}{c}{ Level of Intensity } \\
\cline { 2 - 4 } Interests & Survival & Vital & Major & Peripheral \\
\hline National Interest 1 & & & \\
National Interest 2 & & & \\
$\ldots . .$. & & & \\
National Interest $\mathrm{N}$ & & & \\
\hline
\end{tabular}

Another prominent political scientist, Hans Morgenthau in the '50s of the past century stated: "The meaning of national interest is survival - the protection of physical, political and cultural identity against encroachments by other nationstates." [8]. Also, the author describes "National Interest" as a key concept in international relations. Furthermore, he claims that all the nation-states are constantly engaged in the process of fulfilling or securing the goals of their national interests, and the foreign policy of each nation is formulated based on its national interest. Therefore, it is a universally accepted right of each state to secure its national interests [9]. Finally, Morgenthau defines two levels of national interest, 
the vital and the secondary. Vital interests assure a state its security, its freedom and independence, protection of its institutions, and enshrinement of its values. Vital interests also negate compromise and represent issues over which the state is willing to wage war. Secondary interests are more difficult to define but do involve compromise and negotiation [10] In this way, Morgenthau discusses what the national interest is in the face of the actual world of power politics.

In his study on the concept of the national interest of Hans J. Morgenthau, Ken Kiyono argues that the idea of the national interest has two factors. One is rationally demanded and, therefore, of necessity. The other is changeable and decided by situations. Furthermore, the author maintains that the concept of "national interest" preconceives neither a peaceful and harmonious world based on the eighteenth-century idea of "enlightened self-interest nor the unavoidableness of war as a result of "the pursuit by all nations of their national interest". On the contrarily, "it assumes continuous conflict and threat of war, to be minimised through the continuous adjustment of conflicting interests by diplomatic action" [11].

A well-known definition of the Brookings Institute from the same period explains national interest as "What a nation feels to be necessary to its security and well-being ... National interest reflects the general and continuing ends for which a nation acts" [12].

Approximately a decade later, Charles Lerche and Abdul Said define the concept of national Interest as "The general, long-term and continuing purpose which the state, the nation, and the government all see themselves as serving."

Another well-known political scientist from the sixties years of the $20^{\text {th }}$ century, Vernon Von Dyke argues, "National Interest is, that which states seek to protect or achieve in relation to each other. It means desires on the part of sovereign states" [13].

In recent times, an American political scientist Elmer Plischke discusses the "national interest" concept, and his understanding is that national interests are "those fundamental determinants, intrinsic needs, operational criteria or ultimate standards in accordance with which a nation frames its national purposes and goals" [14].

According to Liotta, "the national interest demands the willingness of a state to uphold its morals and national values with the commitment of its blood, treasure, time, and energy, to achieve sometimes specific and sometimes in specific ends. National interests reflect the identity of the people, i.e. their geography, culture, political sympathies, social consensus, as well as their levels of economic prosperity and demographic makeup. Thus, national interests are little more than a broad set of often abstract guidelines that allow a nation to function the way it believes it best should function" [15].

Similarly, to Morgenthau, Dawn stresses on the vital interests of a state of which survival is the first and foremost interest. A state's independence and territorial integrity come above all other interests [16]. 
In summary, the national interests are defined as the highest level of long-term and comparatively unchangeable national goals that a nation or group of nations aim to achieve.

\section{Methods fOR EVAluation of nAtional INTERESTS}

This section presents a short overview of the existing methods for the evaluation of national interests.

As we discussed in section II, Donald Neuchterlein, using the National interests matrix, suggests a categorization (grouping) of national interests in the following four categories: survival, vital, major, and peripheral and four types: defence, economic, favourable world order, and ideological [7].

Following Neuchterlein's approach, some current authors suggest more practice-oriented classification of national interests for the political decisionmaking process. For example, Liotta suggests grouping national interests in two groups Core Strategic Interests and Interests of Significant Value [15].

The author introduces working definitions of "survival interest" as a nation's physical existence is threatened by an attack. The use of military force is unquestionably advanced in support of survival interests.

Next on the intensity scale are "vital interests" where serious harm to the nation occurs unless dealt with using strong measures, including force. Nations are unwilling to compromise these interests; the maintenance of territorial integrity is an example of vital national interest.

"Major interests" are next on the intensity scale. Similar to vital interests, a primary difference between the two is that use of force is not deemed necessary in the defence of major interests. Finally, "peripheral interests" affect a nation's overall interests but do not really pose a threat to the nation as a whole.

Suggested definitions are expected to enable consistency to be applied in determining what actions and means are necessary to achieve which desired ends.

In addition to the presented National interest matrix of Donald Neuchterlein, it should be added several other possible approaches to evaluate national interests.

One of the most frequently used is the Delphi method, which can be implemented in several rounds of data collection from Subject Matter Experts (SMEs) to achieve consensus among their opinions. This method is originally developed as a systematic, interactive forecasting technique, which counts on a panel of experts. It is based on the principle that forecasts (or evaluations) from a structured group of individuals are more accurate than those from unstructured groups. The experts fill out a questionnaire in two or more rounds depending on when the consensus among them will be achieved. After each round, the expert's study director provides an anonymised summary of the experts' evaluations from the previous round, as well as the reasons they provided for their judgments. Thus, experts are encouraged to review, and possibly revise their earlier answers in light of the replies of the other members of the panel to achieve consensus. The evaluation process can stop after reaching a predefined criterion (e.g., the 
achievement of consensus, fixed number of rounds, stability of results, etc.). Then the basic statistics like mean, mode and median scores of the final results are calculated and interpreted [17], [18 $]^{1}$.

It is important to underline that some authors warn about possible weaknesses and inaccuracy of the Delphi method, which is related to the fact that future developments are not always predicted correctly by the consensus of experts. The typical human factor issue of ignorance is important. If panellists are not informed about a topic, or they maintain very divergent opinions, the use of the Delphi method may not produce proper results [19].

It must also be taken into account that in areas such as science and technology forecasting, the degree of uncertainty is so great that exact and always correct predictions are almost impossible, so a high degree of error is to be expected.

Another methodological issue that has to be taken into account is the limited ability of Delphi to make complex forecasts with multiple factors. Initially, potential future elements were usually considered as if they did not affect each other. Later on, several extensions to the Delphi method were developed to address this problem such as Cross Impact Analysis that takes into consideration the possibility that the occurrence of one event may change probabilities of the other events covered in the survey.

The Cross-Impact Analysis is the umbrella term given to a family of techniques designed to evaluate changes in the probability of occurrence of a set of events arising from the actual occurrence of one. The model was introduced as a tool for reporting interactions between a set of forecasts when these interactions may not be taken into account when making individual estimates. Thus, the Cross-Impact Analysis provides a framework for examining and assessing the impact of multiple related components for future scenarios among themselves, while facilitating additional information about the system's relevant properties [20], [21].

Briefly, the combined application of Delphi and Cross Impact Analysis as possible instruments for data collection and analysis in Subject Matter Experts study will be a successful approach to evaluate the national interests of EU Member States.

Another quantitative methodology for analysis that could be used in the process of prioritisation of national interests and ranking the corresponding security risks is the Analytic Hierarchy Process (AHP). This technique is also useful in prioritisation of different policy options for mitigation of the identified risks and protection of national interests.

The American mathematician Thomas Saaty has developed the method and it became an important instrument in decision-making [5]. It presents a model of native human reasoning in solving decision tasks through a hierarchy of criteria. As

\footnotetext{
${ }^{1}$ For an extensive list of publications regarding using Delphi in forecast process, please see: Futures Methodologies. Delphi

https://www.rand.org/pardee/pubs/futures method/delphi.html.
} 
such, it has been used in several studies in sociology, ecology and economics. An advantage of the method is the nine-point scale for comparing the criteria at each level. Unlike the binary scales, which only allows determining the preference of one object to another, the nine-point scale provides options for determining the degree (intensity) of this preference.

The approach for a National interests prioritization, proposed in this article is an application of the Analytic Hierarchy Process. Next paragraphs will shortly describe the theoretical base of the Analytic hierarchy process.

Let a set of properties of the studied objects (alternatives) is given. These properties (objects) should be prioritized on the basis on a degree of their importance from the point of view of the experts. The task is reduced to selecting a variety of possible permutations:

$\left\{<P_{1}, P_{2}, \ldots, P_{n}>,<P_{1}, P_{3}, \ldots, P_{n}, P_{2}>, \ldots,<P_{n}, P_{n-1}, \ldots, P_{1}>\right.$,

which are relevant to the experts' preferences.

Let $\left\{P_{i}\right\}$ is a set of ranking objects (criteria). Quantitative judgments for pair of objects are a pairwise comparison matrix $n \times n ; A=\left(a_{i j}\right), i, j=1,2, \ldots, n$. The elements $a_{i j}$ are determined according to the following rules:

1. If $a_{i j}=\alpha$, then $a_{j i}=\frac{1}{\alpha}$, for $\alpha \neq 0$.

2. If the properties $P_{i}$ and $P_{j}$ are equally important then $a_{i j}=1$, and $a_{j i}=1$, in particular, $a_{i i}=1$, for $\forall i$.

Consequently, $A=\left(\begin{array}{ccc}1 & \cdots & a_{1 n} \\ \vdots & \ddots & \vdots \\ \frac{1}{a_{1 n}} & \cdots & 1\end{array}\right)$, i.e. $A$ is the symmetrically reciprocal matrix.

Quantitative judgments for pairs of objects $\left(P_{i}, P_{j}\right)$ are set on a multidimensional scale (from 1 to 9 ), relevant to the relative importance of the object $P_{i}$ to the object $P_{j}$. The scale is determined by the following rules:

3. If $P_{i}$ is moderately preferred than $P_{j}$, then $a_{i j}=3$.

4. If $P_{i}$ is strongly preferred than $P_{j}$, then $a_{i j}=5$.

5. If $P_{i}$ is very strongly preferred than $P_{j}$, then $a_{i j}=7$.

6. If $P_{i}$ is extremely more preferred than $P_{j}$, then $a_{i j}=9$.

7. Values $2,4,6,8$ and their reciprocal values are used to reduce tradeoffs between slightly different judgments.

In cases, where the pairwise comparison matrix $A$ satisfies, transitivity for all pairwise comparisons it is said to be consistent and it verifies the following relation - $a_{i j}=a_{i k} * a_{k j}, \forall i, j, k[22]$. 
AHP allows inconsistency but provides a measure of the inconsistency in each set of judgments. The consistency of the pairwise comparison matrix can be determined by a measure called the consistency ratio (CR), defined as [5]:

$$
C R=\frac{C I}{R I}
$$

where $\mathrm{Cl}$ is called the consistency index and $R I$ is the Random Index.

Furthermore, Saaty provided average consistencies ( $R I$ values) of randomly generated matrices (Table 2).

Table 2: The average consistencies of random matrices [5]

\begin{tabular}{|c|c|c|c|c|c|c|c|c|c|c|c|c|c|c|c|}
\hline$n$ & 1 & 2 & 3 & 4 & 5 & 6 & 7 & 8 & 9 & 10 & 11 & 12 & 13 & 14 & 15 \\
\hline$R I$ & 0,00 & 0,00 & 0,58 & 0,9 & 1,12 & 1,24 & 1,32 & 1,41 & 1,45 & 1,49 & 1,51 & 1,48 & 1,56 & 1,57 & 1,59 \\
\hline
\end{tabular}

Cl for a matrix of order $n$ is defined as:

$$
C I=\frac{\lambda_{\max }-n}{n-1}
$$

where $\lambda_{\max }$ is the largest eigenvalue of the pairwise comparison matrix.

In general, a consistency ratio of 0.1 or less is considered acceptable. If the value is higher, the judgments may not be reliable and they should be reviewed.

According to Saaty, to decide an organised way to generate priorities it needs to decompose the decision into the following steps [22]:

1. Define the problem and determine the kind of knowledge sought.

2. Structure the decision hierarchy from the top with the goal of the decision, then the objectives from a broad perspective, through the intermediate levels (criteria on which subsequent elements depend) to the lowest level (which usually is a set of the alternatives).

3. Construct a set of pairwise comparison matrices. Each element in an upper level is used to compare the elements in the level immediately below concerning it.

4. Use the priorities obtained from the comparisons to weigh the priorities in the level immediately below. Do this for every element. Then for each element in the level below add its weighted values and obtain its overall or global priority. Continue this process of weighing and adding until the final priorities of the alternatives in the bottom-most level are obtained.

The AHP is a systematic approach developed in the 1970s to give decisionmaking based on experience, intuition and heuristics the structure of a well-defined methodology derived from sound mathematical principles. It provides a formalised approach where economic justification of the time invested in the decision-making process is provided by the better quality of the solutions to complex problems [[24]. 
There are two types of AHP models [22] - relative models and rating models. In a relative model, all properties (objects) are pairwise compared to establish priorities. In rating model standards (rating categories) are established for the criteria and the alternatives are rated one at a time against them.

The proposed approach is applying the AHP rating model to prioritize (evaluate) the national interests of the EU and/or of its Member States. The main advantage of using ratings is to decrease the number of comparisons and consequently the pairwise comparison matrix.

\section{AN APPROACH TO PRIORITIZE THE NATIONAL INTERESTS}

This section presents a methodology as a set of guidelines to prioritize (evaluate) the national interest. The suggested guidelines are formulated based on the theoretical study of different definitions of the concept of "national interest". Some ideas are also utilised from the case study carried out in Bulgaria with relevant experts to determine national interests. Moreover, the methodology utilises some lessons learned from the review and analysis of the national interests of the PYTHIA consortium countries and the EU. Finally, yet importantly, it combines the three discussed methods in section II: National Interests Matrix, Delphi and Analytic Hierarchy Process. The combination of the three methods is suggested because of the synergic effect of their combined application.

The methodology for evaluation of national interests can be implemented into practice using a panel of relevant experts to evaluate (identify, classify and prioritise) the national interests of a member state or the EU interests as a whole.

- Preliminary step - Selection of the experts

The selection of the experts, which will participate in the evaluation process, is a very important step. The critical methodological requirements to implement expert's study are summarized below.

First, it is necessary to guarantee that the pool of experts in a member state under scrutiny has been represented during the study as much as possible (decision-makers in the defence and security sector, military, technology developers, low enforcement agencies, intelligence and counterintelligence agencies, academia, civil society, media, etc.). This is imperative to guarantee as broad as possible opinions and to include the viewpoints of different stakeholders. To achieve this goal, there are at least two approaches. First, to ask different institutions to identify their relevant experts which means that the institution $X$ identifies the expert $Y$ as a person who will present in the best possible way the position and the viewpoint of the institution. The second approach is to apply "snowball sample" [[25] starting from a list of well-known experts and asking them to recommend their colleagues who are authorities in the field. After several rounds of names collection, the list of experts can be finalized because the names will start to repeat. Both approaches are useful in defining the sample of experts to participate in the evaluation process. 
The second important requirement is to identify the methodology for data collection from the experts. The first option is to use a quantitative methodology (a detailed questionnaire for the experts) to fill out and give their assessments and arguments. The advantage of the qualitative approach is that it provides an opportunity to apply the Delphi method in several rounds of data collection from the SMEs to achieve consensus among their opinions. The other option is to use a qualitative methodology, as the example of the Bulgarian case study utilizing brainstorming, round table discussions, etc. The best option is to apply a combined qualitative and quantitative methodology.

Third, the organiser of the Subject Matter Experts study must start with an information session for presenting the goal, the expected results from the study, a brief presentation of each expert on the panel, introduction of common terminology and briefings on the topics of the study (national interests, threats and security risks). The goal is to achieve a shared situational awareness among the experts because usually before the SMEs study they have a different level of information and knowledge on the topic, use different concepts and definitions and have a different experience in participating in such endeavours. Therefore, it is critical for the success of the study the experts to attain a common initial picture of the situation, to know very well what are the expected results and the sequence of the activities during the study. It is important also from the viewpoint of the motivation, to give them information on how the results will be used and in which way they can influence the decision-making process. Finally, yet importantly, it is recommended that the organizers of the SMEs study to include at least one question that will help prove the level of expertise of the participants. This could be the questions about their level of knowledge, source of information, previous experience, etc.

The suggested next phases and steps for evaluation of the national interests are based on the specific application of the Delphi method and Analytic Hierarchy Process based on data collected from experts and are presented in figure 1. 
Phase I. Problem

1. Identify the national interests

2. Identify decision criteria and rating categories for each criterion

3. Structure the decision hierarchy

Phase II. Evaluation

4. Construct a set of pairwise comparisons in order to obtain the values of importance of the criteria, and priorities of the ratings

5. SMEs study on the matrices, constructed in step 4

6. Calculation the weights of the criteria for each independent expert. Calculation of the consistency ratio of the matrix in order to analyze the consistency of judgments.

7. Calculation the priorities and idealised priorities of rating categories for each criterion for each expert. Calculation of the consistency ratio for each pairwise comparison matrix in order to analvse the consistencv of iudgments.

Phase III. Prioritizing

8. Calculation the priorities of national interests

9. Group aggregation of the individual's expert priorities, including consistency evaluation of expert's opinions.

10. Conducting sensitivity analyses

Figure 1: Phases and steps for evaluation of the national interests 
Step 1 - Identify the national interests

- The combined application of Brainstorming, Roundtable discussion, Delphi method and Cross Impact Analysis is a possible instrument for data collection in expert's study of the identification of the national interests.

- Identify as broad as possible list of national interests (the highest level of the ambition following a nation frames, its national purposes and goals).

Step 2 - Identify decision criteria and rating categories for each criterion

To create a well-managed decision structure, it is recommended the number of criteria to be between three and five [[26]. The rating categories must be clearly defined, in the unambiguous way to adequately describe each criterion.

Our suggestion includes four criteria:

- Criterion "Type of the interest" (based on identified interests of the EU [27]) Rating categories:

- Promote peace and guarantee the security of the citizens and territory - TI1

- Advancement of the prosperity of the citizens - TI2

- Promotion of rules-based favourable global world order - TI3

- Promotion of democratic values and fostering the resilience of our democracies - TI4

Remark: A national interest has to belong just to one rating category.

- Criterion "Intensity of the interest" (based on Donald Neuchterlein publication [7])

Rating categories:

- Survival - II1

- Vital - II2

- Major - 13

- Peripheral - 14

- Criterion "Resources" to protect national interests

Rating categories:

- Completely sufficient - R1

- Almost sufficient - R2

- Partly sufficient - R3

- Insufficient - R4

- Criterion "Knowledge" to protect national interests

Rating categories:

- Completely relevant - K1

- Partly relevant - K2

- Irrelevant - K3. 
All criteria are considered independent, as the AHP method indicates.

Step 3. Structure of the decision hierarchy

Figure 2 presents the hierarchy structure for evaluating (prioritizing) of the national interests.

Goal

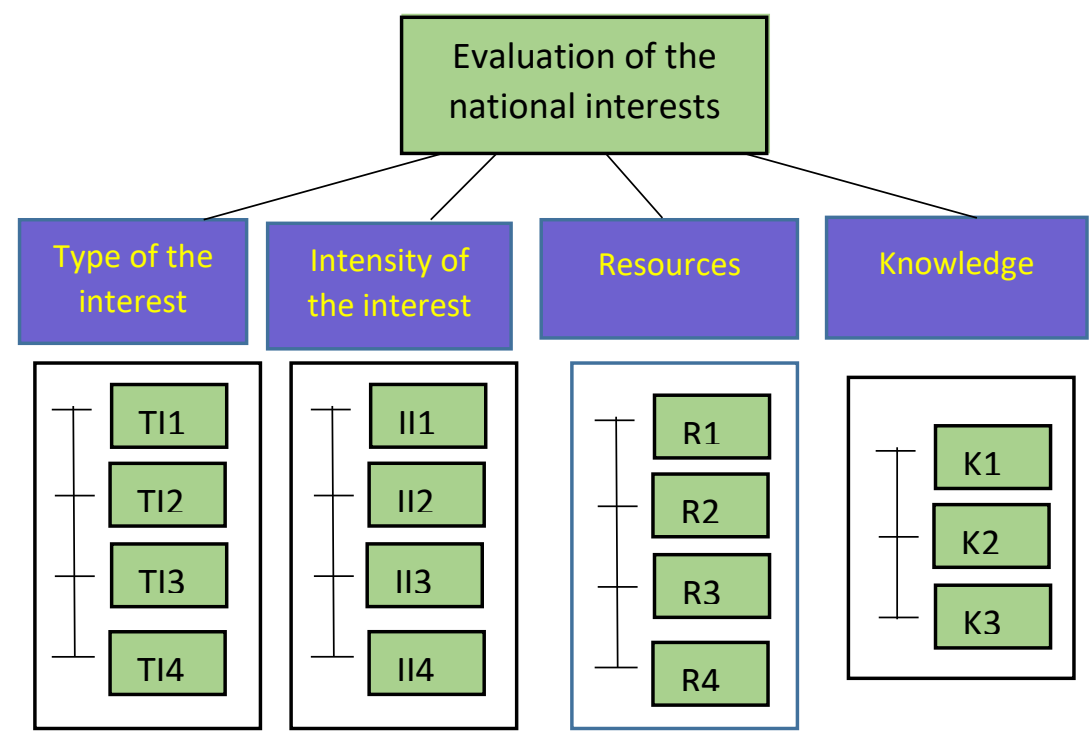

Figure 2: The structure of the decision hierarchy for the evaluation of the national interests

\section{Step 4. Construct a set of pairwise comparison matrices}

In this step, a set of five pairwise comparison matrices are derived to obtain the values of importance (weights) of the criteria and priorities of the rating categories.

Figure 3 presents the pairwise comparison matrix of the criteria concerning the goal.

\begin{tabular}{|l|l|l|l|l|l|}
\hline & Type of interest & $\begin{array}{l}\text { The intensity of } \\
\text { the interest }\end{array}$ & Resources & Knowledge & Priorities \\
\hline Type of interest & 1 & $a$ & $b$ & $c$ & $\mathrm{w}_{1}$ \\
\hline $\begin{array}{l}\text { The intensity of } \\
\text { the interest }\end{array}$ & $1 / a$ & 1 & $d$ & $e$ & $\mathrm{w}_{2}$ \\
\hline Resources & $1 / b$ & $1 / d$ & 1 & $f$ & $\mathrm{w}_{3}$ \\
\hline Knowledge & $1 / c$ & $1 / e$ & $1 / f$ & 1 & $\mathrm{w}_{4}$ \\
\hline
\end{tabular}

Figure 3: The pairwise comparison matrix of the criteria 
where $a, b, c, d, e, f \in\{1 / 9,1 / 8,1 / 7,1 / 6,1 / 5,1 / 4,1 / 3,1 / 2,2,3,4,5,6,7,8,9\}$.

Figure 4 presents the pairwise comparison matrix for calculating priorities of the rating categories for the criterion "Type of the national interest".

\begin{tabular}{|c|c|c|c|c|c|c|}
\hline $\begin{array}{l}\text { Rating } \\
\text { categories } \\
\text { for "Type of } \\
\text { the national } \\
\text { interest" }\end{array}$ & $\begin{array}{l}\text { Promote } \\
\text { peace and } \\
\text { guarantee } \\
\text { the } \\
\text { security of } \\
\text { the } \\
\text { citizens } \\
\text { and } \\
\text { territory } \\
\text { (TI) }\end{array}$ & $\begin{array}{l}\text { Advancement } \\
\text { of the } \\
\text { prosperity of } \\
\text { the citizens } \\
\text { (TI2) }\end{array}$ & $\begin{array}{l}\text { Promotion } \\
\text { of rules- } \\
\text { based } \\
\text { favourable } \\
\text { global } \\
\text { world } \\
\text { order (TI3) }\end{array}$ & $\begin{array}{l}\text { Promotion } \\
\text { of } \\
\text { democratic } \\
\text { values and } \\
\text { fostering } \\
\text { the } \\
\text { resilience of } \\
\text { our } \\
\text { democracies } \\
\text { (TI4) }\end{array}$ & Priorities & $\begin{array}{l}\text { Idealised } \\
\text { Priorities }\end{array}$ \\
\hline $\begin{array}{l}\text { Promote } \\
\text { peace and } \\
\text { guarantee } \\
\text { the security } \\
\text { of the citizens } \\
\text { and territory } \\
\text { (TI1) }\end{array}$ & 1 & $\alpha$ & $\delta$ & $\sigma$ & w11 & $\begin{array}{l}\text { w11/max } \\
\text { (w11, } \\
\text { w12, } \\
\text { w13, } \\
\text { w14) }\end{array}$ \\
\hline $\begin{array}{l}\text { Advancement } \\
\text { of the } \\
\text { prosperity of } \\
\text { the citizens } \\
\text { (TI2) }\end{array}$ & $1 / \alpha$ & 1 & $\gamma$ & $\theta$ & w12 & $\begin{array}{l}\text { w12/max } \\
\text { (w11, } \\
\text { w12, } \\
\text { w13, } \\
\text { w14) }\end{array}$ \\
\hline $\begin{array}{l}\text { Promotion of } \\
\text { rules-based } \\
\text { favourable } \\
\text { global world } \\
\text { order (TI3) }\end{array}$ & $1 / \delta$ & $1 / \gamma$ & 1 & $\eta$ & w13 & $\begin{array}{l}\text { w13/max } \\
\text { (w11, } \\
\text { w12, } \\
\text { w13, } \\
\text { w14) }\end{array}$ \\
\hline $\begin{array}{l}\text { Promotion of } \\
\text { democratic } \\
\text { values and } \\
\text { fostering the } \\
\text { resilience of } \\
\text { our } \\
\text { democracies } \\
\text { (TI3) }\end{array}$ & $1 / \sigma$ & $1 / \theta$ & $1 / \eta$ & 1 & w14 & $\begin{array}{l}\text { w14/max } \\
\text { (w11, } \\
\text { w12, } \\
\text { w13, } \\
\text { w14) }\end{array}$ \\
\hline
\end{tabular}

Figure 4: The pairwise comparison matrix for calculating priorities of the rating categories of the criterion "Type of the national interest"

where $\alpha, \delta, \gamma, \sigma, \vartheta, \eta \in\{1 / 9,1 / 8,1 / 7,1 / 6,1 / 5,1 / 4,1 / 3,1 / 2,2,3,4,5,6,7,8,9\}$.

Analogous matrices are constructed for the rating categories of the criteria "Intensity of the interest", "Resources", and "Knowledge".

Step 5. SMEs study on the matrices, constructed in step 4 
Selected at preliminary step SMEs, fill out pairwise comparison tables. Based on the tables, the matrices, constructed in step 4 are filled in. The judgements in pairwise comparison tables should be based on the rules, described in section III (Saaty's Fundamental Scale).

Step 6. Calculation of the weights of the criteria. Calculation of the consistency ratio of the matrix to analyse the consistency of judgments.

The weights of the criteria and the consistency ratio of the matrix are determined by using the process of the AHP method, described in section III for the decision matrix in figure 3. A consistency ratio is calculated to analyse the consistency of judgments. The consistency ratio of 0.1 or less is acceptable. If the value is higher, the judgments may not be reliable and they should be reviewed.

Step 7. Calculation of the priorities and idealised priorities of rating categories for each criterion. Calculation of the consistency ratio for each pairwise comparison matrix to analyse the consistency of judgments.

The priorities of rating categories for each criterion are calculated according to AHP model, described in section III for the decision matrix in figure 4 and other three analogous decision matrices for the rating categories of the "Intensity of the interest", "Resources", and "Knowledge" criteria. For each matrix, the consistency ratio is calculated to analyse the consistency of judgments. The consistency ratio of 0.1 or less is acceptable. If the value is higher, the judgments may not be reliable and they should be reviewed. Then the obtained priority vectors are idealized [[23], that is, the best category receives the value 1 and the others must be proportionally smaller (see figure 4).

Step 8. Calculation of the priorities of the national interests

For each identified national interest is set up verbal rating on each criterion. Then the verbal ratings are substituted with their corresponding numerical ratings obtained in step 7.

The priorities of national interests ( $\mathrm{NI}$ ) are obtained according to the following formula:

$P_{k}=\sum_{i=1}^{4} w_{i} * i p_{i}^{k}, k=1,2, \ldots$

where

$P_{k}$ is the priority of the $k^{\text {th }}$ National Interest $\left(N I_{k}\right)$,

$w_{i}$ is the priority (weight) of criterion $i, i=1,2,3,4$

$i p_{i}^{k}$ is the idealised priority of the rating category of the National interest $k$, concerning criterion $i, i=1,2,3,4$.

Then these priorities are normalized to obtain the final priorities of National interests. 
Each expert performs independently Steps $5-8$.

Step 9. Group aggregation of the expert's judgments

There are two basic ways to aggregate individual preferences into a group preference, depending on whether the group of experts act together as a unit or as separate individuals. When group behaves like one, group judgments can be set employing a consensus on the pairwise comparisons. We assume that the group consists of individual independent experts and individual judgments should be aggregated. In this case, the method for aggregating individual priorities should be used. An aggregation of each individual's resulting priorities can be computed using either a geometric or arithmetic mean. Neither method will violate the Pareto principle [28]. Inconsistencies among an individual's judgments can be examined and the group can ask individuals to consider revising one or more judgments. It is possible also to be decided to exclude an individual judgement because of inconsistency.

Step 10. Conducting sensitivity analyses

A sensitivity analysis would be required to test under which conditions the ranking of interests may change. The method involves specifying a certain number of experiments, which set different possible combinations of the criteria' weights.

\section{A PRACTICAL EXAMPLE FOR THE EVALUATION OF THE NATIONAL INTERESTS OF THE EU MEMBER StATES}

This example presents the application of the proposed methodology for evaluation of the national interests of the EU Member States, based on Subject Matter Expert's judgements.

The first step is the identification of national interests. Figure 5 presents summarized national interests, which are analysed in D4.3 of the PYTHIA project and are the object of evaluation (prioritization) in this example. The list of the national interests presented in figure 5 is made based on mapping the interests of the PYTHIA Consortium member states. Those interests that are formulated in the same or close way content-wise have been merged. In this way, figure 5 contains 22 distinct national interests of the member states, defined in their strategic documents. 


\section{National Interests}

Guaranteeing the right to preservation, development and expression of ethnic, cultural, linguistic and religious identity of persons belonging to national minorities

Limiting intrusions against personality and property

Prevention and counteraction of corruption and organized crime

Defence against an armed attack directed at national territory, its people and its assets.

Guaranteeing the sovereignty, territorial integrity of the country and security of the borders

Providing infrastructure for the protection of public health and popularization of healthy life habits

Protecting the Constitution-established system and to uphold democratic values

Protection of the environment, increasing people awareness on the subject of environment and rational use of natural resources

Solidarity with its allies in Europe and abroad

Improving good neighbourly relations and ensuring regional stability and inclusion in the Euro-

Atlantic and European political and economic matters

Effective cooperation within structures of the EU and NATO to maintain collective security and to strength European unity

Preserve the security and stability of the European continent and the transatlantic space

Attracting foreign investment and international trade

Overcoming of the negative demographic processes

Development of education, improvement of international scientific cooperation, science and applied activities in the spirit of national and European values

Developing and guaranteeing of IT infrastructure and secure cyberspace

Ensuring economic, financial and social stability and economic prosperity

Preservation and development of the national history, culture and identity

Protecting fundamental human rights and liberties of all citizens

Ensuring country energy security by maintaining reserves of basic resources, diversifying the types of energy and its sources

Protection of the population and critical infrastructure in a time of peace, crises and war

Defending and consolidating constitutional democracy and the rule of law

Providing sources and routes of supply of energy and other strategic raw materials

Figure 5: Identified national interests

Figures 6-12 present the implementation of the steps 2-7 from the methodology in section IV.

The expert has filled out the pairwise comparisons tables (greenfields), presented in figures $6-10$ to derive priorities of the defined in section IV criteria and rating categories. The "Element 1 " field contains the more important element in the comparison of two elements, and the "Judgment" field shows the assessment of how many times Element 1 is more important than other elements. 
Table 2. Judgments of the criteria with respect to the objective 1 = Equal; 3 = Moderate; 5 = Strong; 7 = Very Strong; 9 = Extreme 2=Weak or slight; 4=Moderate Plus; 6=Strong Plus; 8=Very, very strong

\begin{tabular}{|l|r|r|}
\hline \multicolumn{1}{|c|}{ Pairwise } & Element 1 & \multicolumn{1}{|c|}{ Judgement } \\
\hline $\begin{array}{l}\text { Type of the interest (C1) } \\
\text { Intensity of the interest (C2) }\end{array}$ & $\mathrm{C2}$ & 2 \\
\hline $\begin{array}{l}\text { Type of the interest (C1) } \\
\text { Resources (C3) }\end{array}$ & $\mathrm{C} 1$ & 5 \\
\hline $\begin{array}{l}\text { Type of the interest (C1) } \\
\text { Knowledge (C4) }\end{array}$ & $\mathrm{C2}$ & \\
\hline $\begin{array}{l}\text { Intensity of the interest (C2) } \\
\text { Resources (C3) }\end{array}$ & $\mathrm{C2}$ & \\
\hline $\begin{array}{l}\text { Intensity of the interest (C2) } \\
\text { Knowledge (C4) }\end{array}$ & $\mathrm{C} 4$ & 3 \\
\hline $\begin{array}{l}\text { Resources (C3) } \\
\text { Knowledge (C4) }\end{array}$ & & \\
\hline
\end{tabular}

Figure 6: Identified criteria and pairwise comparisons (judgements) 
Table 3 Judgments for deriving priorities for ratings on Type of the national interest

1 = Equal; 3 = Moderate; 5 = Strong; 7 = Very Strong; 9 = Extreme

2=Weak or slight; $4=$ Moderate Plus; 6=Strong Plus; $8=$ Very, very strong

\begin{tabular}{|c|c|c|}
\hline Pairwise & Element 1 & Judgement \\
\hline $\begin{array}{l}\text { Promote peace and guarantee the } \\
\text { security of the citizens and territory } \\
\text { (TI1) } \\
\text { Advancement of the prosperity of the } \\
\text { citizens (TI2) }\end{array}$ & TI1 & 7 \\
\hline $\begin{array}{l}\text { Promote peace and guarantee the } \\
\text { security of the citizens and territory } \\
\text { (TI1) } \\
\text { Promotion of rules-based favourable } \\
\text { global world order (TI3) }\end{array}$ & TI1 & 5 \\
\hline $\begin{array}{l}\text { Promote peace and guarantee the } \\
\text { security of the citizens and territory } \\
\text { (TI1) } \\
\text { Promotion of democratic values and } \\
\text { fostering the resilience of our } \\
\text { democracies (TI4) }\end{array}$ & TI1 & 8 \\
\hline $\begin{array}{l}\text { Advancement of the prosperity of the } \\
\text { citizens (TI2) } \\
\text { Promotion of rules-based favourable } \\
\text { global world order (TI3) }\end{array}$ & TI3 & 3 \\
\hline $\begin{array}{l}\text { Advancement of the prosperity of the } \\
\text { citizens (TI2) } \\
\text { Promotion of democratic values and } \\
\text { fostering the resilience of our } \\
\text { democracies (TI4) }\end{array}$ & TI2 & 4 \\
\hline $\begin{array}{l}\text { Promotion of rules-based favourable } \\
\text { global world order (TI3) } \\
\text { Promotion of democratic values and } \\
\text { fostering the resilience of our } \\
\text { democracies (TI4) }\end{array}$ & TI3 & 5 \\
\hline
\end{tabular}

Figure 7: Pairwise comparisons for deriving priorities for ratings on „Type of the national interest"Identified criteria and pairwise comparisons (judgements)

Table 4 Judgments for deriving priorities for ratings on Intensity of the national interest

1 = Equal; 3 = Moderate; 5 = Strong; 7 = Very Strong; 9 = Extreme

2=Weak or slight; 4=Moderate Plus; 6=Strong Plus; 8=Very, very strong

\begin{tabular}{|l|r|r|}
\hline \multicolumn{1}{|c|}{ Pairwise } & Element 1 & \multicolumn{1}{|c|}{ Judgement } \\
\hline $\begin{array}{l}\text { Survival (II1) } \\
\text { Vital (II2) }\end{array}$ & II1 & 4 \\
\hline $\begin{array}{l}\text { Survival (II1) } \\
\text { Major (II3) }\end{array}$ & II1 & 6 \\
\hline $\begin{array}{l}\text { Survival (II1) } \\
\text { Peripheral (II4) }\end{array}$ & II1 & 8 \\
\hline $\begin{array}{l}\text { Vital (II2) } \\
\text { Major (II3) }\end{array}$ & II2 & 2 \\
\hline $\begin{array}{l}\text { Vital (II2) } \\
\text { Peripheral (II4) }\end{array}$ & II2 & \\
\hline $\begin{array}{l}\text { Major (II3) } \\
\text { Peripheral (II4) }\end{array}$ & II3 & 2 \\
\hline
\end{tabular}

Figure 8: Pairwise comparisons for deriving priorities for ratings on „Intensity of the national interest" 
Table 5 Judgments for deriving priorities for ratings on Resources 1 = Equal; 3 = Moderate; 5 = Strong; 7 = Very Strong; 9 = Extreme 2=Weak or slight; 4=Moderate Plus; 6=Strong Plus; 8=Very, very strong

\begin{tabular}{|l|r|r|}
\hline \multicolumn{1}{|c|}{ Pairwise } & Element 1 & \multicolumn{1}{|c|}{ Judgement } \\
\hline $\begin{array}{l}\text { Completely sufficient (R1) } \\
\text { Almost sufficient (R2) }\end{array}$ & R1 & 5 \\
\hline $\begin{array}{l}\text { Completely sufficient (R1) } \\
\text { Partly sufficient (R3) }\end{array}$ & R1 & 7 \\
\hline $\begin{array}{l}\text { Completely sufficient (R1) } \\
\text { Insufficient (R4) }\end{array}$ & R1 & 9 \\
\hline $\begin{array}{l}\text { Almost sufficient (R2) } \\
\text { Partly sufficient (R3) }\end{array}$ & R2 & 3 \\
\hline $\begin{array}{l}\text { Almost sufficient (R2) } \\
\text { Insufficient (R4) }\end{array}$ & R2 & 5 \\
\hline $\begin{array}{l}\text { Partly sufficient (R3) } \\
\text { Insufficient (R4) }\end{array}$ & R3 & 3 \\
\hline
\end{tabular}

Figure 9: Pairwise comparisons for deriving priorities for ratings on "Resources"

Table 6 Judgments for deriving priorities for ratings on Knowledge

1 = Equal; 3 = Moderate; 5 = Strong; 7 = Very Strong; 9 = Extreme

2=Weak or slight; 4=Moderate Plus; 6=Strong Plus; 8=Very, very strong

\begin{tabular}{|c|c|c|}
\hline Pairwise & Element 1 & Judgement \\
\hline $\begin{array}{l}\text { Completely relevant (K1) } \\
\text { Partly relevant (K2) }\end{array}$ & K1 & 4 \\
\hline $\begin{array}{l}\text { Completely relevant (K1) } \\
\text { Irrelevant (K3) }\end{array}$ & K1 & 9 \\
\hline $\begin{array}{l}\text { Partly relevant (K2) } \\
\text { Irrelevant (K3) }\end{array}$ & $\mathrm{K} 2$ & 4 \\
\hline
\end{tabular}

Figure 10: Pairwise comparisons for deriving priorities for ratings on "Knowledge"

Based on the filled expert's judgements the pairwise comparison matrices are populated and the weights of the criteria and the priorities of the rating categories are computed. Next two figures present the populated matrices. 
An aproach for prioritization of national interests of the EU member states

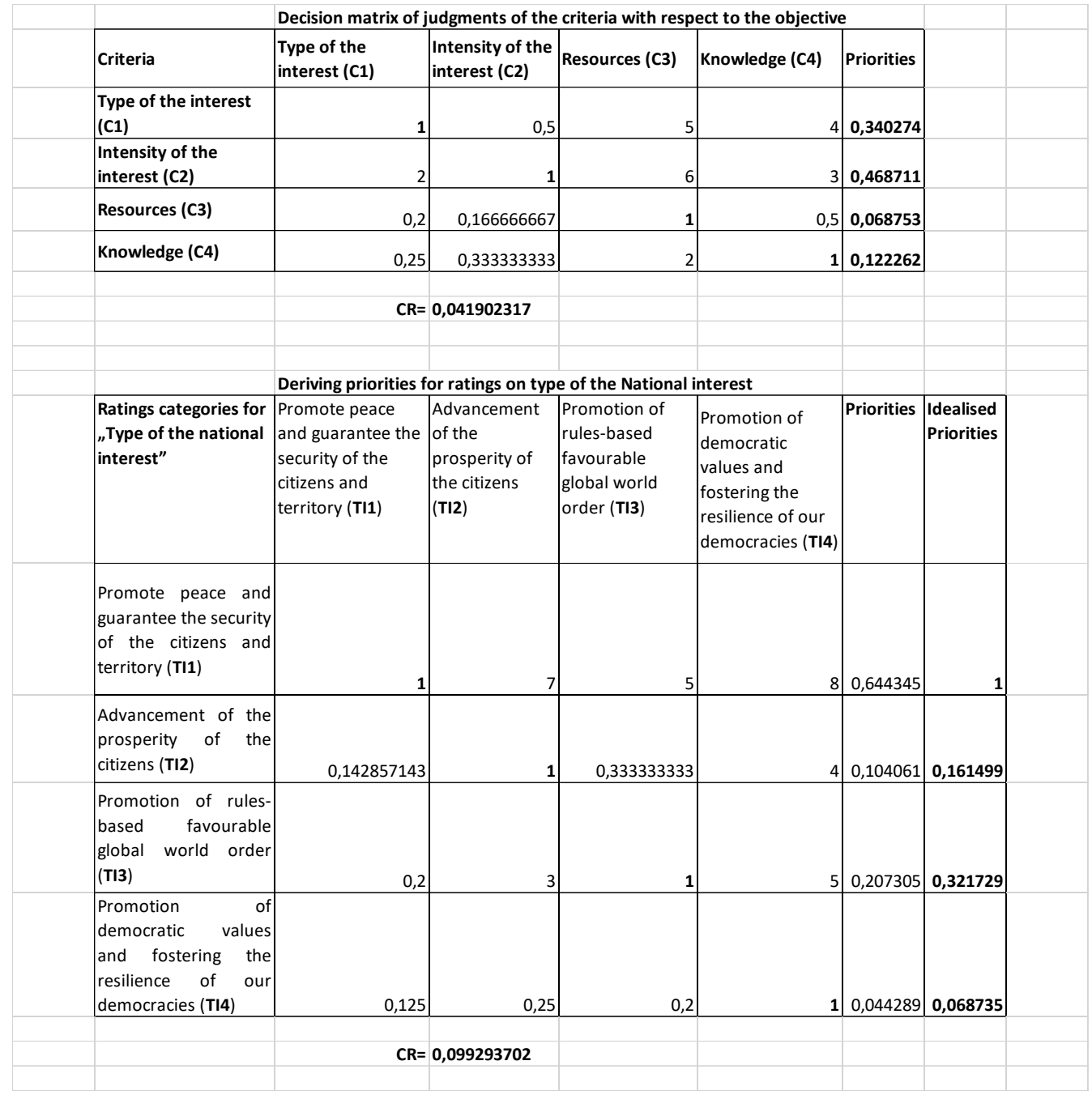

Figure 11: Pairwise comparison matrices for criteria weights and deriving priorities for ratings on "Type of national interest" 
M. Bozhilova, Y. Yanakiev, N. Stoianov, D. Stoyanov, JDST., vol.3, no.4, pp. 55-83, 2020

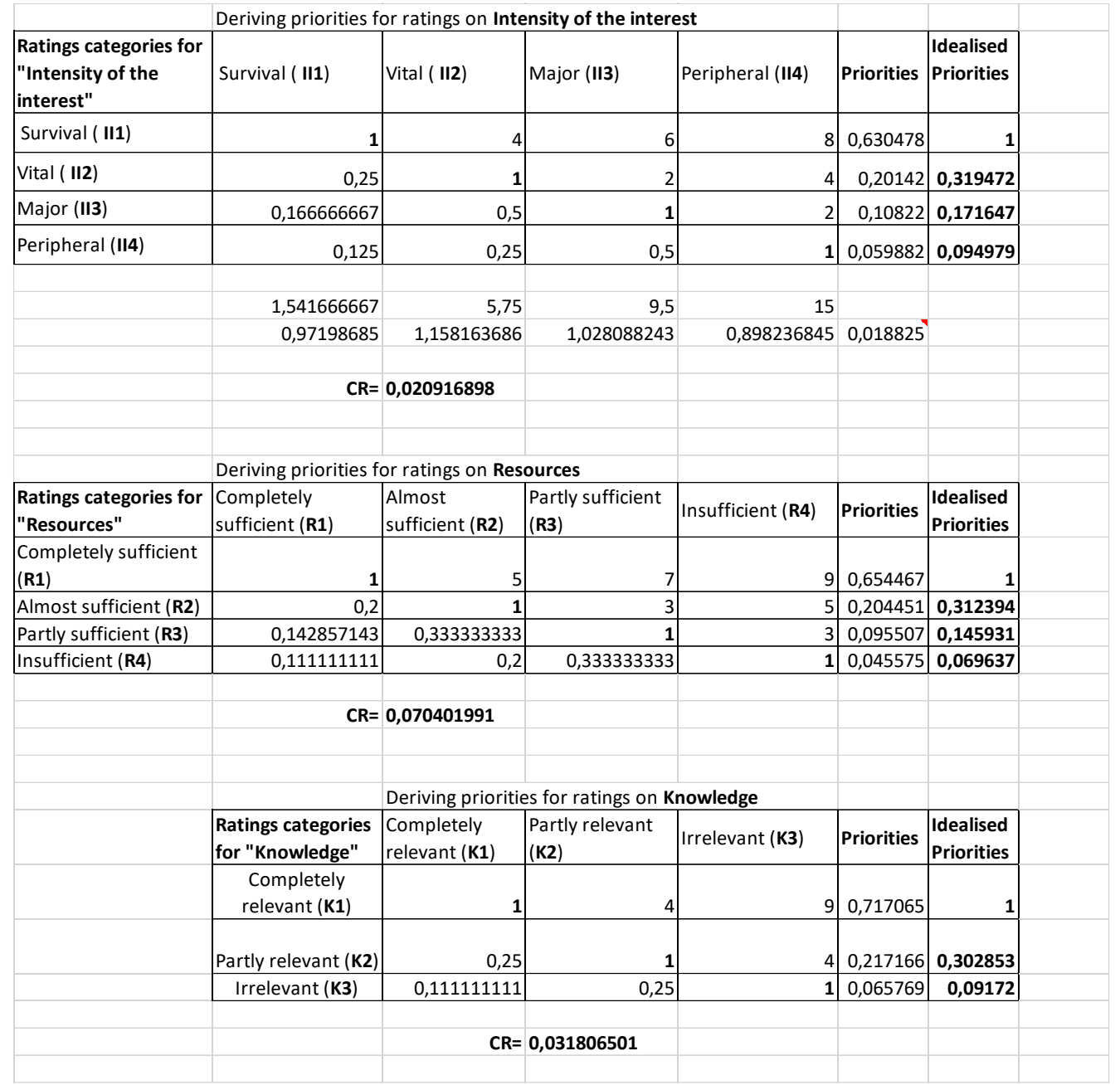

Figure 12: Pairwise comparison matrices for deriving priorities for ratings on "Intensity of interest", "Resources" and "Knowledge"

If the value of CR under a table is greater than 0.1 , it means that judgements in the corresponding table may not be reliable and the expert should review them.

Next step is the assessment of each national interest against the four criteria. The expert should fill in the rating categories (green fields in the table on the figure below) for each national interest concerning each criterion. Figure 13 presents this process already completed. 


\begin{tabular}{|c|c|c|c|c|}
\hline \begin{tabular}{|l|} 
Criteria/ \\
National Interest \\
\end{tabular} & Type of the interest & $\begin{array}{l}\text { Intensity of } \\
\text { the interest }\end{array}$ & Resources & Knowledge \\
\hline $\begin{array}{l}\text { Defence against an armed attack directed at national territory, its } \\
\text { people and its assets. Guaranteeing the sovereignty, territorial } \\
\text { integrity of the country and security of the borders }\end{array}$ & $\begin{array}{l}\text { Promote peace and guarantee the security of the citizens } \\
\text { and territory }\end{array}$ & Survival & $\begin{array}{l}\text { Almost } \\
\text { sufficient }\end{array}$ & Partly relevant \\
\hline $\begin{array}{l}\text { Defending and consolidating constitutional democracy and the } \\
\text { rule of law }\end{array}$ & $\begin{array}{l}\text { Promotion of democratic values and fostering the resilience } \\
\text { of our democracies }\end{array}$ & Major & $\begin{array}{l}\text { Completely } \\
\text { sufficient }\end{array}$ & Irrelevant \\
\hline $\begin{array}{l}\text { Developing and guaranteeing of IT infrastructure and secure } \\
\text { cyberspace }\end{array}$ & Advancement of the prosperity of the citizens & Vital & $\begin{array}{l}\text { Partly } \\
\text { sufficient }\end{array}$ & Partly relevant \\
\hline $\begin{array}{l}\text { Development of education, improvement of international } \\
\text { scientific cooperation, science and applied activities in the spirit of } \\
\text { national and European values }\end{array}$ & Advancement of the prosperity of the citizens & Major & $\begin{array}{l}\text { Almost } \\
\text { sufficient }\end{array}$ & $\begin{array}{l}\text { Completely } \\
\text { relevant }\end{array}$ \\
\hline $\begin{array}{l}\text { Effective cooperation within structures of the EU and NATO in } \\
\text { order to maintain collective security and to strength European } \\
\text { unity }\end{array}$ & $\begin{array}{l}\text { Promote peace and guarantee the security of the citizens } \\
\text { and territory }\end{array}$ & Vital & $\begin{array}{l}\text { Partly } \\
\text { sufficient }\end{array}$ & Partly relevant \\
\hline $\begin{array}{l}\text { Ensuring country energy security by maintaining reserves of basic } \\
\text { resources, diversifying the types of energy and its sources }\end{array}$ & Advancement of the prosperity of the citizens & Major & Insufficient & Irrelevant \\
\hline $\begin{array}{l}\text { Ensuring economic, financial and social stability and economic } \\
\text { prosperity }\end{array}$ & Advancement of the prosperity of the citizens & Vital & Insufficient & Partly relevant \\
\hline $\begin{array}{l}\text { Guaranteeing the right to preservation, development and } \\
\text { expression of ethnic, cultural, linguistic and religious identity of } \\
\text { persons belonging to national minorities }\end{array}$ & Promotion of rules-based favourable global world order & Survival & $\begin{array}{l}\text { Partly } \\
\text { sufficient }\end{array}$ & $\begin{array}{l}\text { Completely } \\
\text { relevant }\end{array}$ \\
\hline $\begin{array}{l}\text { Improving good neighbourly relations and ensuring regional } \\
\text { stability and inclusion in the Euro-Atlantic and European political } \\
\text { and economic matters }\end{array}$ & $\begin{array}{l}\text { Promote peace and guarantee the security of the citizens } \\
\text { and territory }\end{array}$ & Vital & $\begin{array}{l}\text { Almost } \\
\text { sufficient }\end{array}$ & Partly relevant \\
\hline Limiting intrusions against personality and property; & Promotion of rules-based favourable global world order & Survival & $\begin{array}{l}\text { Completely } \\
\text { sufficient }\end{array}$ & Irrelevant \\
\hline Overcoming of the negative demographic processes; & $\begin{array}{l}\text { Promotion of democratic values and fostering the resilience } \\
\text { of our democracies }\end{array}$ & Vital & $\begin{array}{l}\text { Completely } \\
\text { sufficient }\end{array}$ & $\begin{array}{l}\text { Completely } \\
\text { relevant }\end{array}$ \\
\hline $\begin{array}{l}\text { Preservation and development of the national history, culture and } \\
\text { identity }\end{array}$ & Advancement of the prosperity of the citizens & Peripheral & $\begin{array}{l}\text { Completely } \\
\text { sufficient }\end{array}$ & Partly relevant \\
\hline $\begin{array}{l}\text { Preserve the security and stability of the European continent and } \\
\text { the transatlantic space }\end{array}$ & $\begin{array}{l}\text { Promote peace and guarantee the security of the citizens } \\
\text { and territory }\end{array}$ & Vital & $\begin{array}{l}\text { Partly } \\
\text { sufficient }\end{array}$ & Partly relevant \\
\hline Prevention and counteraction of corruption and organized crime & Promotion of rules-based favourable global world order & Survival & Insufficient & Irrelevant \\
\hline Protecting fundamental human rights and liberties of all citizens & Advancement of the prosperity of the citizens & Major & $\begin{array}{l}\text { Almost } \\
\text { sufficient }\end{array}$ & Partly relevant \\
\hline $\begin{array}{l}\text { Protection of the environment, increasing people awareness on } \\
\text { subject of environment and rational use of natural resources }\end{array}$ & Advancement of the prosperity of the citizens & Vital & $\begin{array}{l}\text { Completely } \\
\text { sufficient }\end{array}$ & $\begin{array}{l}\text { Completely } \\
\text { relevant }\end{array}$ \\
\hline $\begin{array}{l}\text { Protection of the population and critical infrastructure in time of } \\
\text { peace, crises and war }\end{array}$ & $\begin{array}{l}\text { Promotion of democratic values and fostering the resilience } \\
\text { of our democracies }\end{array}$ & Vital & \begin{tabular}{|l|}
$\begin{array}{l}\text { Partly } \\
\text { sufficient }\end{array}$ \\
\end{tabular} & Partly relevant \\
\hline $\begin{array}{l}\text { Providing infrastructure for protection of public health and } \\
\text { popularization of prolife and healthy life habits; }\end{array}$ & Advancement of the prosperity of the citizens & Survival & Insufficient & Partly relevant \\
\hline $\begin{array}{l}\text { Providing sources and routes of supply of energy and other } \\
\text { strategic raw materials }\end{array}$ & $\begin{array}{l}\text { Promotion of democratic values and fostering the resilience } \\
\text { of our democracies }\end{array}$ & Major & $\begin{array}{l}\text { Partly } \\
\text { sufficient }\end{array}$ & Irrelevant \\
\hline Attracting foreign investment and international trade & Promotion of rules-based favourable global world order & Peripheral & Insufficient & Partly relevant \\
\hline Solidarity with its allies in Europe and abroad & $\begin{array}{l}\text { Promote peace and guarantee the security of the citizens } \\
\text { and territory }\end{array}$ & Major & $\begin{array}{l}\text { Partly } \\
\text { sufficient }\end{array}$ & $\begin{array}{l}\text { Completely } \\
\text { relevant }\end{array}$ \\
\hline $\begin{array}{l}\text { Protecting the Constitution-established system and to uphold } \\
\text { democratic values }\end{array}$ & $\begin{array}{l}\text { Promotion of democratic values and fostering the resilience } \\
\text { of our democracies }\end{array}$ & Survival & $\begin{array}{l}\text { Almost } \\
\text { sufficient }\end{array}$ & Partly relevant \\
\hline
\end{tabular}

Figure 13: Judgements of national interests

Final steps are implemented on the "Prioritization of the interests" sheet. The priority of each identified national interest is calculated, by substitution of the linguistic rating categories (figure 13) by the corresponding number values (figure 14). Figure 15 presents the results of the prioritization of the national interest, based on individual expert judgements. 


\begin{tabular}{|c|c|c|c|c|c|c|}
\hline National interests & \begin{tabular}{|c|}
$\begin{array}{c}\text { Type of the } \\
\text { interest }\end{array}$ \\
\end{tabular} & \begin{tabular}{|l|} 
Intensity of \\
the interest \\
\end{tabular} & Resources & Knowledge & Totals & Priorities \\
\hline & 0,34027437 & 0,46871069 & 0,068753 & 0,12226198 & & \\
\hline $\begin{array}{l}\text { Defence against an armed attack directed at national } \\
\text { territory, its people and its assets. Guaranteeing the } \\
\text { sovereignty, territorial integrity of the country and } \\
\text { security of the borders }\end{array}$ & 1 & 1 & 0,312394 & 0,30285343 & 0,86749053 & 0,097090947 \\
\hline $\begin{array}{l}\text { Defending and consolidating constitutional democracy } \\
\text { and the rule of law }\end{array}$ & 0,06873541 & 0,17164726 & 1 & 0,0917202 & 0,18380866 & 0,020572163 \\
\hline $\begin{array}{l}\text { Developing and guaranteeing of IT infrastructure and } \\
\text { secure cyberspace }\end{array}$ & 0,16149931 & 0,31947155 & 0,1459311 & 0,30285343 & 0,251754462 & 0,028176768 \\
\hline $\begin{array}{l}\text { Development of education, improvement of } \\
\text { international scientific cooperation, science and } \\
\text { applied activities in the spirit of national and European } \\
\text { values }\end{array}$ & 0,16149931 & 0,17164726 & 0,312394 & 1 & 0,279146973 & 0,031242582 \\
\hline $\begin{array}{l}\text { Effective cooperation within structures of the EU and } \\
\text { NATO in order to maintain collective security and to } \\
\text { strength European unity }\end{array}$ & 1 & 0,31947155 & 0,1459311 & 0,30285343 & 0,537074754 & 0,060110277 \\
\hline $\begin{array}{l}\text { Ensuring country energy security by maintaining } \\
\text { reserves of basic resources, diversifying the types of } \\
\text { energy and its sources }\end{array}$ & 0,16149931 & 0,17164726 & 0,0696368 & 0,0917202 & 0,151408613 & 0,016945897 \\
\hline $\begin{array}{l}\text { Ensuring economic, financial and social stability and } \\
\text { economic prosperity }\end{array}$ & 0,16149931 & 0,31947155 & 0,0696368 & 0,30285343 & 0,246509004 & 0,027589688 \\
\hline $\begin{array}{l}\text { Guaranteeing the right to preservation, development } \\
\text { and expression of ethnic, cultural, linguistic and } \\
\text { religious identity of persons belonging to national } \\
\text { minorities }\end{array}$ & 0,32172944 & 1 & 0,1459311 & 1 & 0,710482148 & 0,079518314 \\
\hline $\begin{array}{l}\text { Improving good neighbourly relations and ensuring } \\
\text { regional stability and inclusion in the Euro-Atlantic and } \\
\text { European political and economic matters }\end{array}$ & - & 0,31947155 & 0,312394 & 0,30285343 & 0,548519571 & 0,0613912 \\
\hline Limiting intrusions against personality and property; & 0,32172944 & 1 & 1 & 0,0917202 & 0,65815383 & 0,073661644 \\
\hline Overcoming of the negative demographic processes; & 0,06873541 & 0,31947155 & 1 & 1 & 0,364143571 & 0,040755539 \\
\hline $\begin{array}{l}\text { Preservation and development of the national history, } \\
\text { culture and identity }\end{array}$ & 0,16149931 & 0,09497946 & 1 & 0,30285343 & 0,205252387 & 0,02297218 \\
\hline $\begin{array}{l}\text { Preserve the security and stability of the European } \\
\text { continent and the transatlantic space }\end{array}$ & 1 & 0,31947155 & 0,1459311 & 0,30285343 & 0,537074754 & 0,060110277 \\
\hline $\begin{array}{l}\text { Prevention and counteraction of corruption and } \\
\text { organized crime }\end{array}$ & 0,32172944 & 1 & 0,0696368 & 0,0917202 & 0,594188604 & 0,066502552 \\
\hline $\begin{array}{l}\text { Protecting fundamental human rights and liberties of } \\
\text { all citizens }\end{array}$ & 0,16149931 & 0,17164726 & 0,312394 & 0,30285343 & 0,193912454 & 0,021702996 \\
\hline $\begin{array}{l}\text { Protection of the environment, increasing people } \\
\text { awareness on subject of environment and rational use } \\
\text { of natural resources }\end{array}$ & 0,16149931 & 0,31947155 & 1 & 1 & 0,395708749 & 0,044288365 \\
\hline $\begin{array}{l}\text { Protection of the population and critical infrastructure } \\
\text { in time of peace, crises and war }\end{array}$ & 0,06873541 & 0,31947155 & 0,1459311 & 0,30285343 & 0,220189284 & 0,024643942 \\
\hline $\begin{array}{l}\text { Providing infrastructure for protection of public health } \\
\text { and popularization of prolife and healthy life habits; }\end{array}$ & 0,16149931 & 1 & 0,0696368 & 0,30285343 & 0,565479963 & 0,063289434 \\
\hline $\begin{array}{l}\text { Providing sources and routes of supply of energy and } \\
\text { other strategic raw materials }\end{array}$ & 0,06873541 & 0,17164726 & 0,1459311 & 0,0917202 & 0,125088892 & 0,014000152 \\
\hline Attracting foreign investment and international trade & 0,32172944 & 0,09497946 & 0,0696368 & 0,30285343 & 0,195809368 & 0,021915302 \\
\hline Solidarity with its allies in Europe and abroad & 1 & 0,17164726 & 0,1459311 & 1 & 0,553022448 & 0,061895169 \\
\hline $\begin{array}{l}\text { Protecting the Constitution-established system and to } \\
\text { uphold democratic values }\end{array}$ & 0,06873541 & 1 & 0,312394 & 0,30285343 & 0,55060506 & 0,061624611 \\
\hline
\end{tabular}




\begin{tabular}{|c|c|c|}
\hline 1 & $\begin{array}{l}\text { Defence against an armed attack directed at national } \\
\text { territory, its people and its assets. Guaranteeing the } \\
\text { sovereignty, territorial integrity of the country and } \\
\text { security of the borders }\end{array}$ & 0,09709095 \\
\hline 2 & $\begin{array}{l}\text { Guaranteeing the right to preservation, development } \\
\text { and expression of ethnic, cultural, linguistic and } \\
\text { religious identity of persons belonging to national } \\
\text { minorities }\end{array}$ & 0,07951831 \\
\hline 3 & Limiting intrusions against personality and property; & 0,07366164 \\
\hline 4 & $\begin{array}{l}\text { Prevention and counteraction of corruption and } \\
\text { organized crime }\end{array}$ & 0,06650255 \\
\hline 5 & $\begin{array}{l}\text { Providing infrastructure for protection of public health } \\
\text { and popularization of prolife and healthy life habits; }\end{array}$ & 0,06328943 \\
\hline 6 & Solidarity with its allies in Europe and abroad & 0,06189517 \\
\hline 7 & $\begin{array}{l}\text { Protecting the Constitution-established system and to } \\
\text { uphold democratic values }\end{array}$ & 0,06162461 \\
\hline 8 & $\begin{array}{l}\text { Improving good neighbourly relations and ensuring } \\
\text { regional stability and inclusion in the Euro-Atlantic and } \\
\text { European political and economic matters }\end{array}$ & 0,0613912 \\
\hline 9 & $\begin{array}{l}\text { Effective cooperation within structures of the EU and } \\
\text { NATO in order to maintain collective security and to } \\
\text { strength European unity }\end{array}$ & 0,06011028 \\
\hline 10 & $\begin{array}{l}\text { Preserve the security and stability of the European } \\
\text { continent and the transatlantic space }\end{array}$ & 0,06011028 \\
\hline 11 & $\begin{array}{l}\text { Protection of the environment, increasing people } \\
\text { awareness on subject of environment and rational use } \\
\text { of natural resources }\end{array}$ & 0,04428836 \\
\hline 12 & Overcoming of the negative demographic processes; & 0,04075554 \\
\hline 13 & $\begin{array}{l}\text { Development of education, improvement of } \\
\text { international scientific cooperation, science and } \\
\text { applied activities in the spirit of national and European } \\
\text { values }\end{array}$ & 0,03124258 \\
\hline 14 & $\begin{array}{l}\text { Developing and guaranteeing of IT infrastructure and } \\
\text { secure cyberspace }\end{array}$ & 0,02817677 \\
\hline 15 & $\begin{array}{l}\text { Ensuring economic, financial and social stability and } \\
\text { economic prosperity }\end{array}$ & 0,02758969 \\
\hline 16 & $\begin{array}{l}\text { Protection of the population and critical infrastructure } \\
\text { in time of peace, crises and war }\end{array}$ & 0,02464394 \\
\hline 17 & $\begin{array}{l}\text { Preservation and development of the national history, } \\
\text { culture and identity }\end{array}$ & 0,02297218 \\
\hline 18 & Attracting foreign investment and international trade & 0,0219153 \\
\hline 19 & $\begin{array}{l}\text { Protecting fundamental human rights and liberties of } \\
\text { all citizens }\end{array}$ & 0,021703 \\
\hline 20 & $\begin{array}{l}\text { Defending and consolidating constitutional democracy } \\
\text { and the rule of law }\end{array}$ & 0,02057216 \\
\hline 21 & $\begin{array}{l}\text { Ensuring country energy security by maintaining } \\
\text { reserves of basic resources, diversifying the types of } \\
\text { energy and its sources }\end{array}$ & 0,0169459 \\
\hline 22 & $\begin{array}{l}\text { Providing sources and routes of supply of energy and } \\
\text { other strategic raw materials }\end{array}$ & 0,01400015 \\
\hline
\end{tabular}

Figure 15: The prioritized national interests 
This simple example verifies and validates the proposed methodology for prioritization (evaluation) the national interests of the EU Member States, based on an individual's expert judgements.

\section{CONCLUSIONS AND FUTURE WORK}

The evaluation of national interests is the first important step in defence policymaking and defence strategy development. To implement an effective defence policy, it must be based on proper identification and prioritisation of national interests. After that the threats to the interests should be identified, the resources needed, and the corresponding defence strategy to protect national goals.

The conducted research shows that the approach, based on the Analytic Hierarchy Process is a powerful instrument for the prioritization (evaluation) of the national interests. The method for selection of Subject matter experts is a key component, to be able the proposed methodology to be effectively used.

Next step is to assess the impact of technology trends on future defence capabilities building to protect national interests.

Using as input the prioritized national interests, we will focus on defence interest (defence of national/EU territory and sovereignty) among other national interests and assess the impact of the identified new disruptive technologies on eight capability imperatives development (DOTMLPF-I). As a result, we expect to prioritize the defence technologies, applying the described methodology of Saaty (AHP rating mode) to identify which disruptive technology among the identified ones will have the most important impact on the development of the future defence capabilities (operationalized as 8 imperatives DOTMLPF-I).

\section{ACKNOWLEDGEMENTS}

This article is based on the results achieved in the framework of the EU project Predictive methodologY for TecHnology Intelligence Analysis (PYTHIA).

PYTHIA has received funding from the European Union's

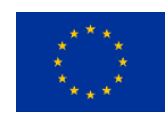

Preparatory Action on Defence Research under grant agreement No 800893.

The information contained in this document reflects only the author's view and the European Defence Agency is not responsible for any use that may be made of the information it contains.

\section{REFERENCES}

[1]. PYTHIA project web site - http://www.pythia-padr.eu/landingpage

[2]. I. Hristozov, "An information technology application in an integrated collaborative environment", Proceedings of Scientific Conference with 
international participation Military Technologies \& Systems 2013 (MT\&S2013), Sofia, 2014, ISSN 2367-5942, pp. II-101 - II-108 (in Bulgarian)

[3]. G. Velev, "A formal description of an ad hoc on-demand distance vector routing protocol for mobile ad hoc networks", Proceedings of Scientific Conference with international participation Military Technologies \& Systems 2013 (MT\&S-2013), Sofia, 2014, pp. II-15 - II-24, ISSN 2367-5942 (in Bulgarian)

[4]. R. Iliev, K. Ignatova, "Implementation of Cloud Technologies for Building Data Centers", in Defence and Security. Information \& Security: An International Journal 43, no. 1 (2019): 89-97 pp, https://doi.org/10.11610/isij.4308

[5]. T.L. Saaty, "The Analytic Hierarchy Process", McGraw-Hill, New York, 1980.

[6]. D. Neuchterlein, "National Interest and Foreign Policy: A Conceptual Framework for Analysis and Decision-Making", Vol. 2, No. 3, British Journal of International Studies, 1976, p. 246.

[7]. D. Neuchterlein, "National Interests and National Strategy," in Terry L. Heyns, ed., Understanding U.S. Strategy: A Reader, Washington, DC: National Defense University, 1983, p. 38.

[8]. H. J. Morgenthau, "Politics among Nations: The Struggle for Power and Peace", 2d ed., rev. \& enl. New York: Knopf., 1948

[9]. H. J Morgenthau, "A Critical Examination of American Foreign Policy", In Defense of the National Interest: New York: Knopf., 1951

[10]. H. J. Morgenthau, "The Impasse of American Foreign Policy", Chicago: Univ. of Chicago, 1962, p. 191.

[11]. "Study on the concept of the national Interest of Hans J. Morgenthau: as the standard of American foreign policy", NAOSITE: Nagasaki University's Academic Output SITE, http://naosite.lb.nagasakiu.ac.jp/dspace/bitstream/10069/27783/1/keieikeizai49_03_04.pdf, 1969, pp.1-20.

[12]. "Major Problems of United States' Foreign Policy", Washington D.C: The Brookings Institution, 1953

[13]. V. Van Dyke, "Values and Interests. American Political Science Review" 56:567-576, 1962

[14]. "Foreign Relations - Analysis of its Anatomy", Issue 213 of Contributions in political science, Greenwood Press, 1988

[15]. P. H. Liotta, "To Die For: National Interests and Strategic Uncertainties," in Strategy and Force Planning, Newport, RI: Naval War College Press, 2004, pp. 46-57.

[16]. Dawn "National Interests and Diplomacy", 2010), http://www.dawn.com/news/846325/national-interests-and-diplomacy, accessed on 10 November 2018.

[17]. C. Okoli, S. D.Pawlowski, "The Delphi method as a research tool: an example, design considerations and applications", Elsevier, Information \& 
Management Volume 42, Issue 1, December 2004, Pages 15-29, https://doi.org/10.1016/j.im.2003.11.002

[18]. "The Delphi Method: Techniques and Applications", Harold A. Linstone and Murray Turoff, Editors (C) 2002, Murray Turoff and Harold Linstone, TOC III.B.3. The National Drug-Abuse Policy Delphi: Progress Report and Findings to Date, IRENE ANNE JILLSON, http://is.njit.edu/pubs/delphibook/ch3b3.htm.

[19]. K. C. Green, J. S. Armstrong, A. Graefe, "Methods to elicit forecasts from groups: Delphi and prediction markets compared", Foresight: The International Journal of Applied Forecasting, 8, 2007, pp. 17-20.

[20]. G. Matic, M. Berry, "Cross-Impact Analysis as a research pattern", available from http://designresearchtechniques.com/casestudies/crossimpact-analysis-as-a-research-pattern/, accessed on 3.01.2019.

[21]. Th. Gordon, "Cross-Impact Method", available from http://citeseerx.ist.psu.edu/viewdoc/download?doi=10.1.1.202.7337\&rep =rep1\&type=pdf, accessed on 3.01.2019.

[22]. M. Berrittella, A. Certa, M. Enea, P. Zito., "An Analytic Hierarchy Process for The Evaluation of Transport Policies to Reduce Climate Change Impacts", available from http://www.feem.it/Feem/Pub/Publications/WPapers/default.htm, accessed on 10.01.2019

[23]. T. L. Saaty, "Decision making with the analytic hierarchy process", Int. J. Services Sciences, Vol. 1, No. 1, 2008.

[24]. N. Bhushan, K. Rai, "Strategic Decision Making", Springer-Verlag London Limited, 2004

[25]. "Snowball sampling", available from https://researchmethodology.net/sampling-in-primary-data-collection/snowballsampling/, accessed on 10.01.2019.

[26]. C. K. Murphy, "Limits of the analytical hierarchy process from its consistency index", Eur J Oper Res., 1993; 65:138-9.

[27]. "A Global Strategy for the European Union's Foreign and Security Policy: Shared Vision, Common Action: A Stronger Europe", 2016, available on https://eeas.europa.eu/archives/docs/top_stories/pdf/eugs_review_web. pdf, accessed on 12.09.2018.

[28]. E. Forman, K. Peniwati, "Aggregating individual judgments and priorities with the Analytic Hierarchy Process", European Journal of Operational Research, 108 (1998) 165-169 